\title{
Nerve Growth Factor Regulates Sympathetic Ganglion Cell Morphology and Survival in the Adult Mouse
}

\author{
Kenneth G. Ruit,, Patricla A. Osborne, ${ }^{2}$ Robert E. Schmidt, ${ }^{3}$ Eugene M. Johnson, Jr., ${ }^{2}$ and William D. Snider ${ }^{1}$ \\ Departments of ${ }^{1}$ Neurology, ${ }^{2}$ Pharmacology, and ${ }^{3}$ Pathology, Washington University School of Medicine, St. Louis, \\ Missouri 63110
}

\begin{abstract}
We have investigated the effects of prolonged systemic injections of nerve growth factor (NGF) and its antiserum on the survival and morphology of sympathetic ganglion cells in adult mice. Using intracellular injections of Lucifer yellow in lightly fixed superior cervical ganglia, we show that total dendritic lengths of ganglion cells are increased $29 \%$ after 2 weeks of NGF treatment. The increased dendritic length is characterized by increased branching within the dendritic arborization and not by the addition of new primary dendrites. In addition, cell soma cross-sectional area was increased $45 \%$. Conversely, administration of NGF antiserum for 1 month decreased total dendritic length by $33 \%$, decreased ganglion cell body size by $26 \%$, and reduced the number of neurons in the ganglion by $25 \%$. After 3 months of NGF antiserum treatment, the number of neurons in the ganglion was reduced a total of $41 \%$. NGF antiserum treatment for 1 month in aged (22 months old) animals reduced ganglion cell body size by $21 \%$ and cell number by $22 \%$, decreases that are comparable to those observed in young adult animals. Our results indicate that, even in maturity, sympathetic ganglion cells remain dependent on NGF for survival and maintenance of dendritic geometry, and this dependence continues into old age.
\end{abstract}

Sympathetic ganglion cells, which depend on ncrve growth factor (NGF) for survival and differentiation during early development, are thought to be considerably less dependent on this molecule as development proceeds. In vitro, ganglion cells from animals at early developmental stages cannot survive more than $48 \mathrm{hr}$ without NGF in the medium (Chun and Patterson, 1977; Greene, 1977; Martin et al., 1988), whereas these neurons from mature animals may no longer require NGF for survival (Johnson, 1983; see also Lindsay, 1988). In vivo, administration of NGF antiserum to newborn animals results in almost complete destruction of sympathetic ganglia (Levi-Montalcini and Booker, 1960; Levi-Montalcini and Angeletti, 1966), and axotomyinduced target deprivation of sympathetic ganglion cells in the neonatal period leads to massive cell death (Hendry and Campbell, 1976). However, after 3 weeks of age, NGF antiserum treatment results in less extensive destructive effects on sym-

Received Feb. 5, 1990; revised March 26, 1990; accepted April 2, 1990.

This work was supported by NIH grants to W.D.S., E.M.J., and R.E.S. We thank P. Amargo, J. Colombo, and S. Plurad for technical assistance.

Correspondence should be addressed to Dr. William D. Snider, Department of

Neurology, Washington University School of Medicine, Box 8111, 660 South Euclid Avenue, St. Louis, MO 63110.

Copyright (C) 1990 Society for Neuroscience $0270-6474 / 90 / 072412-08 \$ 03.00 / 0$ pathetic ganglia, and discontinuation of treatment leads to ultimate recovery of sympathetic function (Angeletti et al., 1971a; Bjerre et al., 1975b).

Although NGF dependence is less acute in adult animals, long-term exposure to NGF antibodies in autoimmune animals leads to substantial sympathetic ganglion cell death in animals with high antibody titers (Gorin and Johnson, 1980; Johnson et al., 1982). Further evidence of continued NGF dependence is the occurrence of cellular atrophy and decreases in transmitter enzymes after treatment with specific antisera (Angeletti et al., 1971a; Goedert et al., 1978; Otten et al., 1979). Conversely, exogenous administration of NGF in the adult animal results in sympathetic target hyperinnervation and increased target levels of neurotransmitter (Bjerre et al., 1975a) and sympathetic ganglion cell hypertrophy (Angeletti et al., 1971b). Furthermore, intraventricular infusions of NGF can prevent neuronal atrophy and cell death produced by separation of basal forebrain cholinergic neurons from their hippocampal target after fimbriafornix lesions (Hefti, 1986; Williams et al., 1986; Kromer, 1987) and can cause increases in CAT staining and cellular hypertrophy of uninjured neurons in the basal forebrain and striatum in adult animals (Hagg et al., 1989; Higgins et al., 1989).

An aspect of sympathetic ganglion cell dependence on NGF that has not previously been investigated in adult animals is the regulation of ncuronal morphology. A recently described action of exogenously administered NGF is the enhancement of dendritic arborizations of sympathetic ganglion cells during development. Injection of NGF into newborn rats markedly increases total dendritic length and the number of primary dendrites per ganglion cell (Snider, 1988). Furthermore, experimental manipulation of target size in the neonatal period also significantly affects dendritic morphology; creating a larger than normal target expands dendritic arborizations and increases the number of primary dendrites, whereas creating a smaller target inhibits normal dendritic development (Voyvodic, 1989).

The potential sensitivity of the dendrites of mature neurons to NGF is of particular interest because it has been demonstrated that the dendritic arborizations of rodent sympathetic ganglion cells undergo considerable growth and rearrangement in maturity (Purves and Hadley, 1985; Purves et al., 1986a; Voyvodic, 1987). Furthermore, axotomy of sympathetic postganglionic fibers in adult mice results in decreases in ganglion cell crosssectional area and total dendritic length. Reinnervation of the target, however, soon brings these parameters back to control levels (Yawo, 1987). These experiments suggest a role for targetderived neurotrophic factors in the regulation of the dendritic arborizations of sympathetic ganglion cells, even in adult ani- 
mals. Since NGF is known to affect dendritic arborization during development, it is a natural candidate to regulate these changes in maturity.

In this study, we have performed a detailed investigation of the response of sympathetic ganglion cells in mature mice to NGF deprivation or administration of exogenous NGF. We have chosen to study sympathetic ganglion cells because they are susceptible to the effects of systemically administered NGF or NGF antiserum. Furthermore, their accessibility for intracellular staining permits investigation of the responses of their dendritic arborizations to NGF or anti-NGF treatment. Finally, the number of cells within a ganglion can be counted directly without the necessity for specific enzyme (Hefti, 1986; Williams et al., 1986; Kromer, 1987) or receptor staining (Richardson et al., 1986; Taniuchi et al., 1986), techniques necessary to identify NGF-dependent populations of neurons within the central nervous system.

\section{Materials and Methods}

$N G F$ and anti-NGF treatment. Mouse 2.5S NGF was purified from male mouse submandibular glands according to the method of Bocchini and Angeletti (1969), dissolved in phosphate-buffered saline $(0.1 \mathrm{M}, \mathrm{pH}$ 7.4), and administered daily to young adult female mice (CF1 strain, 20-25 gm, 6-8 weeks old, Charles River Laboratories) by subcutaneous injection in a dosage of $5 \mathrm{mg} / \mathrm{kg}$. A comparable dose is known to increase sympathetic ganglion cell size, enhance transmitter enzyme synthesis, and enhance sympathetic ganglion cell dendritic arborizations in newborns (Thoenen et al., 1971; Snider, 1988). The animals were treated for 2 weeks and compared with age- and weight-matched controls that had been either untreated or treated with cytochrome $C$, a protein with physical properties similar to NGF.

Young female guinea pigs were immunized with mouse 2.5S NGF as previously described (Rich et al., 1984), and serum antibody titers were determined by the embryonic chick dorsal root ganglion bioassay (Fenton, 1970; Gorin and Johnson, 1979). Young adult female CF1 mice received injections of guinea pig serum $(0.5 \mathrm{ml} /$ injection $)$ with antibody titers against mouse NGF of 1000 . Animals were treated twice a week for either 1 month or 3 months. After treatment the animals were compared with other animals of the same age and weight which either had been untreated or had received injections of nonimmune guinea pig serum as controls. In addition to treatment of young adult animals, aged female mice (CFW strain, 22-24 months old, acquired from a colony maintained by the National Institute on Aging and Charles River Laboratories) were treated twice weekly for 1 month with NGF antiserum. The results from treated aged animals were compared to values obtained from untreated aged controls.

Intracellular staining. Animals were killed by intraperitoneal injections of sodium pentobarbital $(200 \mathrm{mg} / \mathrm{kg})$ and perfused transcardially with a physiological mammalian Ringer's solution. The superior cervical ganglia were dissected from adjacent tissue, removed, pinned through the pre- and postganglionic nerves on a small piece of Sylgard (Dow Corning Corp.), and fixed by immersion in $4 \%$ paraformaldehyde in $0.1 \mathrm{M}$ sodium phosphate buffer for $30-35 \mathrm{~min}$. After fixation the ganglia were kept in a dish containing $0.1 \mathrm{M}$ sodium phosphate buffer.

Microelectrodes with DC resistances between 60 and $100 \mathrm{M} \Omega$ in 0.1 $\mathrm{M} \mathrm{LiCl}$ were pulled from thick-walled omega dot-type capillaries (OD/ ID $1.0 / 0.58 \mathrm{~mm}$, WPI) on a Flaming-Brown P-87 micropipette puller (Sutter Instruments). The tips of the electrodes were bent to a $90^{\circ}$ angle by a hot filament to facilitate vertical penetration of cells with a horizontally positioned electrode. The electrode tips were filled with a $10 \%$ solution of Lucifer yellow (LY-CH, Sigma) dissolved in $0.1 \mathrm{M} \mathrm{LiCl}$. The electrodes were backfilled with $0.1 \mathrm{M} \mathrm{LiCl}$ and attached to a micromanipulator.

The ganglia were placed in a chamber containing $0.1 \mathrm{M}$ sodium phosphate buffer on a fixed-stage Leitz Laborlux microscope. Visualization of the ganglion cells was facilitated by oblique fiberoptic illumination (Purves and Hadley, 1985; Purves et al., 1986a; Yawo, 1987). Neurons on the surface of the ganglion were impaled under direct visual guidance by using long-working-distance objectives (Leitz EF 4/0.12, EF L20/ 0.32 , Zeiss $40 / 0.75 \mathrm{~W}$ ), and the cells were filled with LY-CH by iontophoresis (pulsed negative current, 3-5 nA for 5-8 min) until the tips of the dendrites were brightly fluorescent as visualized with an epifluorescence filter for Lucifer yellow (Leitz I2/3 cube).

Selection of ganglion cells for intracellular filling was performed by focusing down on the surface of the ganglion at the outset of the experiment and impaling the cell that fell under the cross-hairs in the ocular of the microscope. Subsequent cell selections were made by moving the microscope stage so that the soma and distal processes of the previously injected cell were completely removed from the field. The ganglion cell on which the cross-hairs fell was the next ccll sclected for impalement. By using this technique, 8-10 cells per ganglion could be injected intracellularly without overlap of their dendritic processes and without selection bias on the part of the investigator.

After intracellular filling, the ganglia were postfixed in $4 \%$ paraformaldehyde at $4^{\circ} \mathrm{C}$ for $2-3 \mathrm{hr}$. After fixation the ganglia were dehydrated through a graded series of ethanol, cleared in xylene, and coverslipped with Krystalon (Harleco). The cells in the whole mount preparations were viewed under fluorescein epifluorescence, photographed, and traced on black paper with a white pencil by using a Leitz $50 \times$ water immersion objective (NA 1.00) and a camera lucida drawing tube attachment. Dendrites and axons were identified as previously described (Snider, 1988); dendrites contained secondary and tertiary branches whereas axons were smooth, unbranched processes that could be followed for several hundred microns until they exited in the postganglionic trunks. Cells were rejected from the analysis if the axon could not be followed for at least $100 \mu \mathrm{m}$.

Several quantitative measures of dendritic morphology were determined. The number of primary dendrites was obtained by viewing the cell at $500 \times$ in multiple focal planes. A primary dendrite was identified as a dendritic process that arose from the ganglion cell soma and extended a distance greater than the diameter of the cell soma. Total dendritic length was determined by tracing a cell's dendritic arborization from a camera lucida drawing on a digitizing tablet interfaced with a computer program designed for neuronal imaging (Voyvodic, 1986). The maximum extent of the arborization, which is essentially the extent of the longest dendrite, was measured as the radius of a circle that incorporated the entire dendritic arbor. Dendritic branching was determined by counting the number of dendritic branch points. A dendritic branch point was identified as a point that gave rise to branches which either continued to exhibit further branching or were greater than $5 \mu \mathrm{m}$ in length, after the criteria of Ramoa et al. (1988). Finally, as an additional measure of dendritic branching, the number of dendritic processes, which crossed a circle drawn at $50 \%$ of the radius of the circle that incorporated the entire dendritic arbor, was counted (Scholl, 1953).

Statistical analysis of the data was made by comparing the NGFtreated group and the NGF antiserum-treated group to their appropriate control groups by using a 2 -tailed Student's $t$-test.

Sympathetic ganglion cell counts and cellular profiles. Groups of animals were treated with NGF or NGF antiserum according to the previously described protocol. The animals were killed by overdose injections of sodium pentobarbital $(200 \mathrm{mg} / \mathrm{kg})$ and perfused transcardially with a physiological mammalian Ringer's solution followed by $10 \%$ formalin in $0.1 \mathrm{M}$ phosphate buffered saline. The superior cervical and stellate ganglia were removed and placed in vials containing $10 \%$ formalin. The superior cervical ganglia were embedded in paraffin, cut serially into $8 \mu \mathrm{m}$ sections, and stained with toluidine blue. The stellate ganglia were processed for electron microscopy by postfixation in buffered $\mathrm{OsO}_{4}$, dehydration in graded alcohols and propylene oxide, and embedding in Spurr's medium. Thin sections were stained with uranyl acetate and lead citrate and examined with a Philips 200 electron microscope. Semithin $(1 \mu \mathrm{m})$ plastic sections of stellate ganglia were cut and stained with toluidine blue for determination of cellular crosssectional areas. Ultrastructural analysis and determination of crosssectional areas were performed in stellate rather than superior cervical ganglia so that fewer adult animals had to undergo the costly NGF treatment protocol. We have assumed that the observations made in 1 ganglion after treatment also pertained to the other.

Cell numbers in right superior cervical ganglia were determined by counting nuclear profiles in every third or fourth section of a ganglion at $500 \times$ and correcting the raw count with a correction factor that took into account the thickness of the section and the average nuclear diameters (Abercrombie, 1946). Cross-sectional areas of the ganglion cell somata from the stellate ganglia were traced on a digitizing tablet from camera lucida drawings by using computer software designed to calculate areas (SigmaScan, Jandel Scientific). The cell count and crosssectional area data from experimental animals were compared to the 

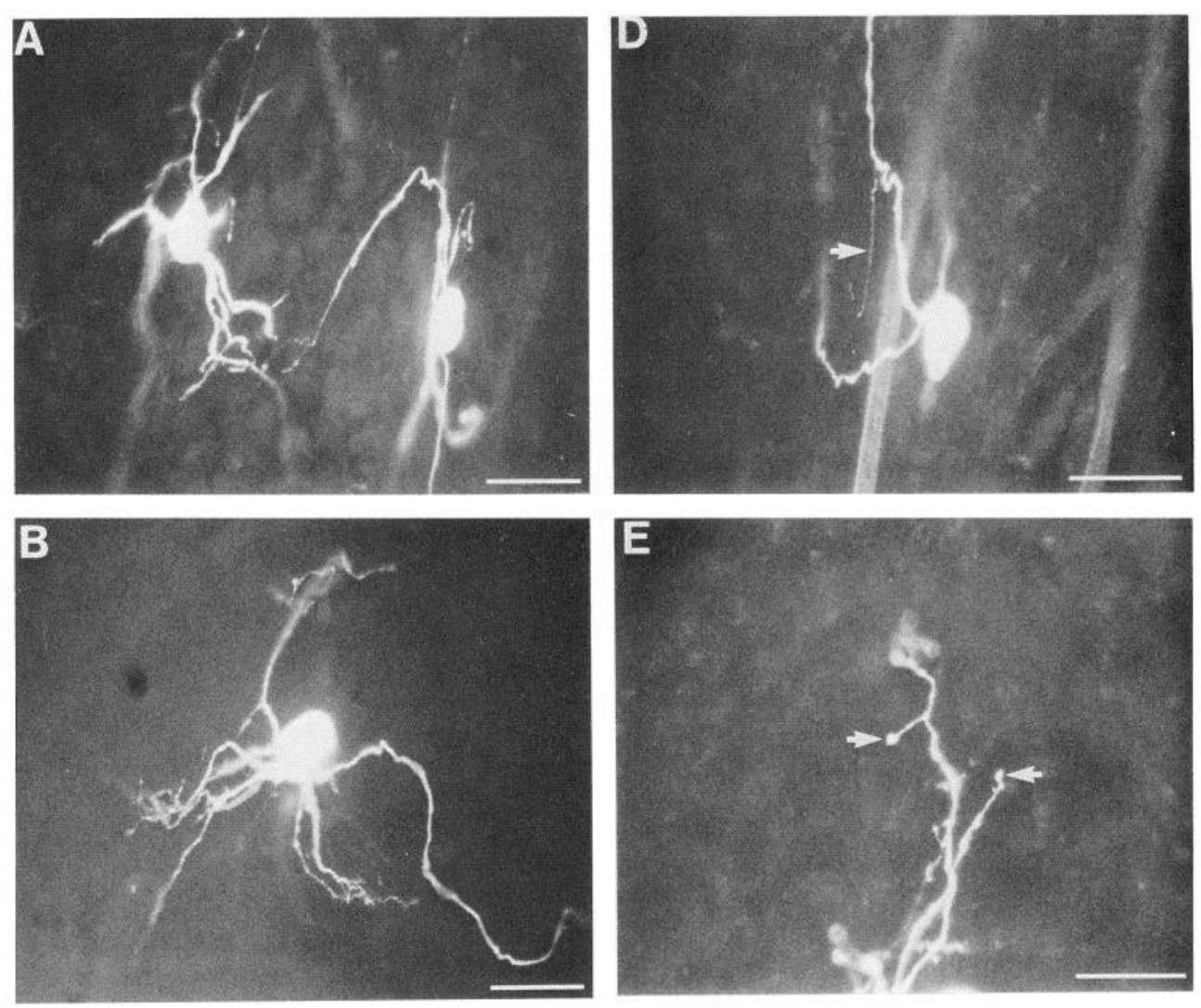

Figure 1. A-E, Photomicrographs of superior cervical ganglion cells that have been intracellularly stained with Lucifer yellow. Cells from NGF-treated animals $(B)$ were larger and exhibited more dendritic branching than controls $(A)$. Conversely, cells from NGF antiserum-treated animals $(C)$ were smaller and the dendritic arborizations were less complex. NGF antiserum-treated cells also exhibited very thin dendritic sprouts $(D$, arrow $)$ and contained branches terminating in swellings or club-like endings ( $E$, arrows). Scale bars: $A-D, 50 \mu \mathrm{m} ; E, 25 \mu \mathrm{m}$.

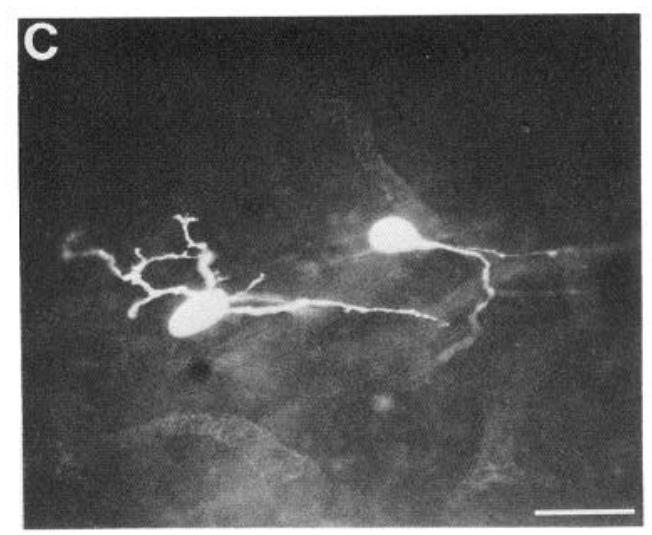

data accumulated from control animals by using a 2-tailed Student's $t$-test.

\section{Results}

\section{Intracellular staining in fixed tissue}

Light fixation of the superior cervical ganglion facilitated cell membrane penetration by microelectrodes. Immersion fixation in $4 \%$ paraformaldehyde for $30 \mathrm{~min}$ proved to be the optimum fixation time; times of either shorter or longer duration were not conducive to cell penetration or optimum dye diffusion. Intracellular staining of lightly fixed ganglion cells by iontophoretic injection of Lucifer yellow produced excellent labeling of neurons and their dendritic arborizations to their distal tips (Fig. 1). The dye remained stable within the cells, especially after postfixation at $4^{\circ} \mathrm{C}$, and cells could be drawn by camera lucida weeks after the experiments. We were confident that the dye filled the entire dendritic arbor because the mean value for total dendritic length of cells in our control population for NGF antiserum treatment $(877 \mu \mathrm{m} \pm 33$ SEM, Table 1) matched previously published control values $(896 \mu \mathrm{m} \pm 35$ SEM) from cells injected with HRP in the living ganglia of the same strain of mouse at comparable ages and weights (Yawo, 1987).

\section{Changes in dendritic morphology after NGF or NGF antiserum treatment}

Figures 2 and 3 are camera lucida drawings of representative superior cervical ganglion cells from appropriate control and experimental treatment groups. Each treatment group was compared to an appropriate group of age- and weight-matched, untreated controls. NGF-treated animals were 8-10 weeks old and weighed less than $26 \mathrm{gm}$ (mean: $23.5 \mathrm{gm}$, range: $20.5-25.8 \mathrm{gm}$ ). They were therefore matched with control animals at comparable ages weighing less than 26 gm (mean: $23.5 \mathrm{gm}$, range: 

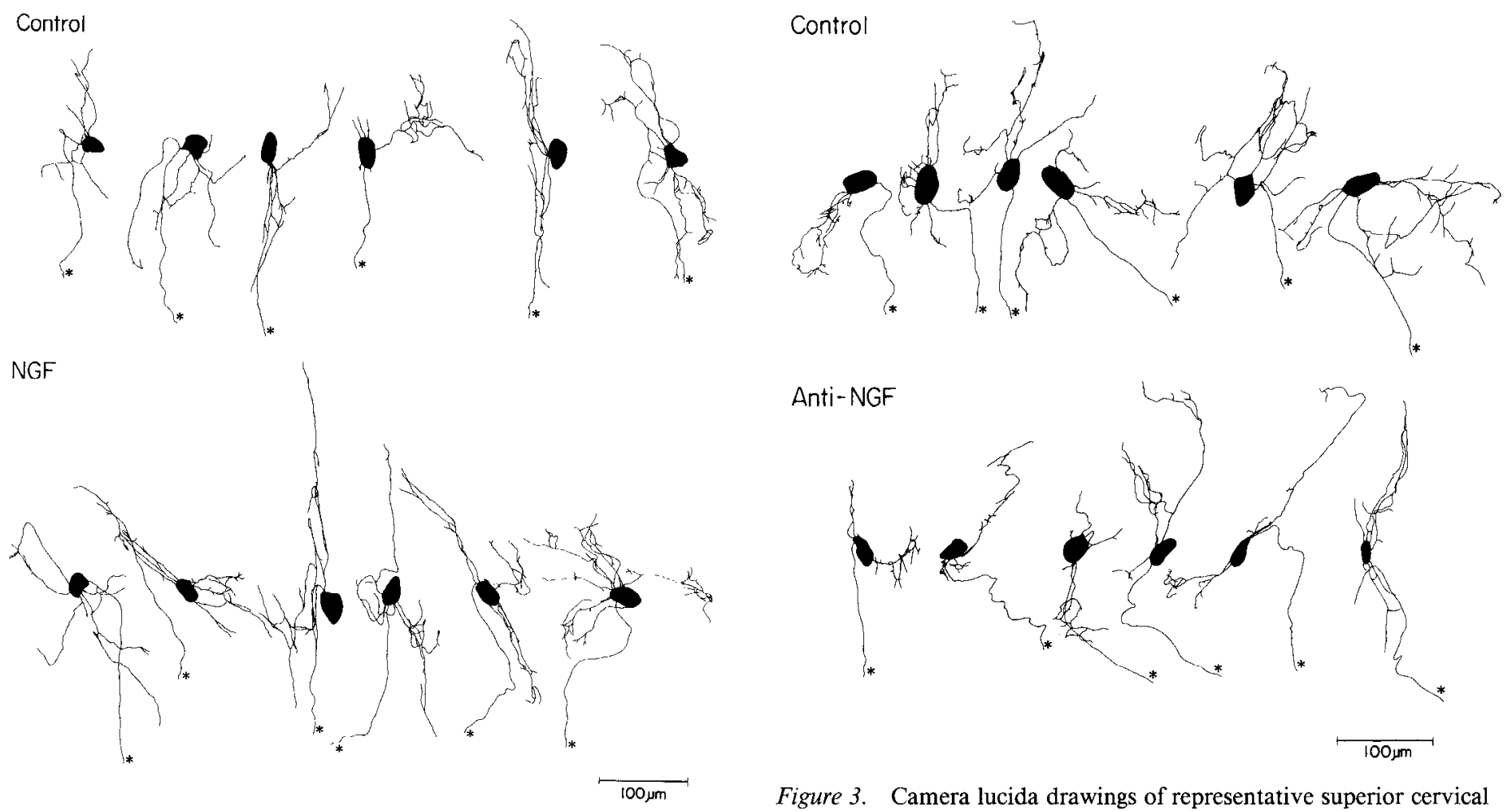

Figure 3. Camera lucida drawings of representative superior cervical ganglion cells illustrating the dendritic morphologies of cells from a control group compared to a group that has been treated with NGF antiserum. In each group every tenth cell was selected and the cells were arranged in order of increasing total dendritic lengths. Cells from NGF antiserum-treated animals were significantly smaller and exhibited decreased dendritic branching when compared to controls. The axon is indicated by an asterisk $\left(^{*}\right)$.

Figure 2. Camera lucida drawings of representative superior cervical ganglion cells illustrating the dendritic morphologies of cells from a control group compared to a group that has been treated with NGF. In each group, every fifteenth cell was selected and the cells were arranged in order of increasing total dendritic lengths. Cells from NGF-treated animals were significantly larger and exhibited increased total dendritic lengths characterized by increased branching when compared to controls. The axon is indicated by an asterisk $\left({ }^{*}\right)$.

22.0-24.6 gm). NGF antiserum-treated animals were 10-12 weeks old (because of the longer treatment period) and weighed more than 26 gm (mean: $29.3 \mathrm{gm}$, range: $26.8-31.0 \mathrm{gm}$ ). They were therefore matched with control animals of comparable age weighing more than $26 \mathrm{gm}$ (mean: $28.8 \mathrm{gm}$, rangc: $26.0-31.5$ $\mathrm{gm})$. That animal weights are comparable in control and experimental groups is important because increases in total dendritic length are known to be strongly correlated with increases in weight through the postnatal development growth period (Voyvodic, 1987; Yawo, 1987).

After 2 weeks of daily administered NGF, sympathetic ganglion cells in adult animals exhibited a $29 \%$ increase in total dendritic length compared to controls (Table 1). The increases in total dendritic length were primarily due to increased dendritic branching. Both the total number of dendritic branch points per cell and the number of branches crossing a circle drawn halfway between the center of the cell soma and the farthest extent of the arborization were significantly increased. Some characteristics of dendritic morphology were not affected by NGF treatment. For example, although the mean extent of

\begin{tabular}{|c|c|c|c|c|c|c|c|c|}
\hline $\begin{array}{l}\text { Treatment } \\
\text { group }\end{array}$ & $\begin{array}{l}\text { Animal } \\
\text { size }(\mathrm{gm})\end{array}$ & $\begin{array}{l}\text { Num- } \\
\text { ber of } \\
\text { ani- } \\
\text { mals }\end{array}$ & $\begin{array}{l}\text { Num- } \\
\text { ber of } \\
\text { cells }\end{array}$ & $\begin{array}{l}\text { Total } \\
\text { dendritic } \\
\text { length } \\
(\mu \mathrm{m})\end{array}$ & $\begin{array}{l}\text { Primary } \\
\text { dendrites }\end{array}$ & $\begin{array}{l}\text { Branch } \\
\text { points }\end{array}$ & $\begin{array}{l}\text { Maximum } \\
\text { extent of } \\
\text { arboriza- } \\
\text { tion }(\mu \mathrm{m})\end{array}$ & $\begin{array}{l}\text { Branches } \\
\text { crossing } \\
50 \% \text { circle }\end{array}$ \\
\hline Control & $23.5(0.2)$ & 11 & 101 & $721(26)$ & $3.7(0.2)$ & $10.5(0.5)$ & $146(4)$ & $4.2(0.2)$ \\
\hline NGF & $23.5(0.6)$ & 9 & 123 & $929(27)^{a}$ & $3.9(0.1)$ & $13.7(0.5)^{a}$ & $154(4)$ & $5.2(0.2)^{b}$ \\
\hline Control & $28.8(0.5)$ & 13 & 66 & $877(33)$ & $3.2(0.2)$ & $12.7(0.7)$ & $168(7)$ & $4.2(0.3)$ \\
\hline Anti-NGF & $29.3(0.6)$ & 7 & 80 & $587(24)^{a}$ & $3.0(0.1)$ & $7.2(0.4)^{a}$ & $150(12)$ & $3.5(0.2)^{c}$ \\
\hline
\end{tabular}

Mean values are given \pm SEM.

${ }^{a}$ Values significantly different from controls ( $p<0.001$ by Student's $t$-test).

"Values significantly different from controls ( $p<0.005$ by Student's $t$-test).

' Values significantly different from controls ( $p<0.05$ by Student's $t$-test). 
the dendritic arbor (length of the longest dendrite) was increased slightly, it was not significantly different from control values $(p$ $>0.2$ ). In addition, no significant increase in the number of primary dendrites was observed $(p>0.1)$, in contrast to the results of similar experiments in newborn rats (Snider, 1988).

In response to treatment with NGF antiserum, adult sympathetic ganglion cells exhibited a 33\% decrease in total dendritic length characterized by significant decreases in the number of dendritic branch points per cell and the number of branches extending beyond a $50 \%$ circle. As with administration of NGF, the decreases in the maximum extent of the dendritic arbor and the number of primary dendrites were not significantly different from control values ( $p>0.1, p>0.3$, respectively). Additionally, although the dendritic arborizations were less extensive, some neurons elaborated very thin sprouts (Fig. $1 D$ ), originating either directly from the cell body or occasionally from the axon. Many dendritic processes exhibited small swellings or club-like endings at their tips (Fig. 1E). Similar structures were observed by Yawo (1987) after axotomy. These changes were not observed in any other groups.

\section{Neuronal cell body changes}

Cross-sectional areas of sympathetic ganglion cell somata in adult animals were also significantly affected by NGF or NGF antiserum treatment (Table 2, Fig. 4). After 2 weeks of treatment with NGF, stellate ganglion cell cross-sectional areas were increased $45 \%$ compared to controls that had been treated with cytochrome C. In contrast, after 1 month of treatment with NGF antiserum, soma cross-sectional areas were decreased $26 \%$ compared to controls that had been treated with nonimmune guinea pig serum. After 3 months of antiserum treatment, cell soma cross-sectional areas were $32 \%$ smaller than cells normally at that age.

Ultrastructural examination of NGF antiserum-treated stellate ganglia confirmed the light microscopic impression of atrophy of primary sympathetic neurons. The most striking alteration of subcellular organelles of atrophic neurons was the decrease, occasionally marked, of perikaryal stacked aggregates of rough endoplasmic reticulum (Nissl substance). Residual stacks of membrane, presumably the remains of Nissl depopulated of ribosomes, were scattered throughout the perikarya. Axons and remaining dendrites did not contain unusually increased or decreased amounts or arrangements of neurofilaments and neurotubules, although shrinkage of the perikaryon after NGF antiserum treatment makes a nonquantitative appreciation of the total amount of cytoskeletal elements problematic. Conversely, treatment with NGF resulted in the increase in size of many neurons and a relative increase in the amount of Nissl substance, presumably a reflection of an increase in protein synthetic capacity. Again, no qualitative changes in the number or arrangement of cytoskeletal elements were demonstrated, although quantitative morphometric methods were not utilized.

\section{Effects of NGF antiserum on cell survival}

In addition to causing somatic atrophy and retraction of dendritic arborizations, treatment with NGF antiserum resulted in significant cell death in these adult animals. Cell counts in the right superior cervical ganglion in control animals treated with nonimmune serum were similar to those reported previously for untreated animals of the same strain (Purves et al., 1986b). Cell counts in the right superior cervical ganglion of NGF antiserum-treated animals revealed that, after 1 month of treat-
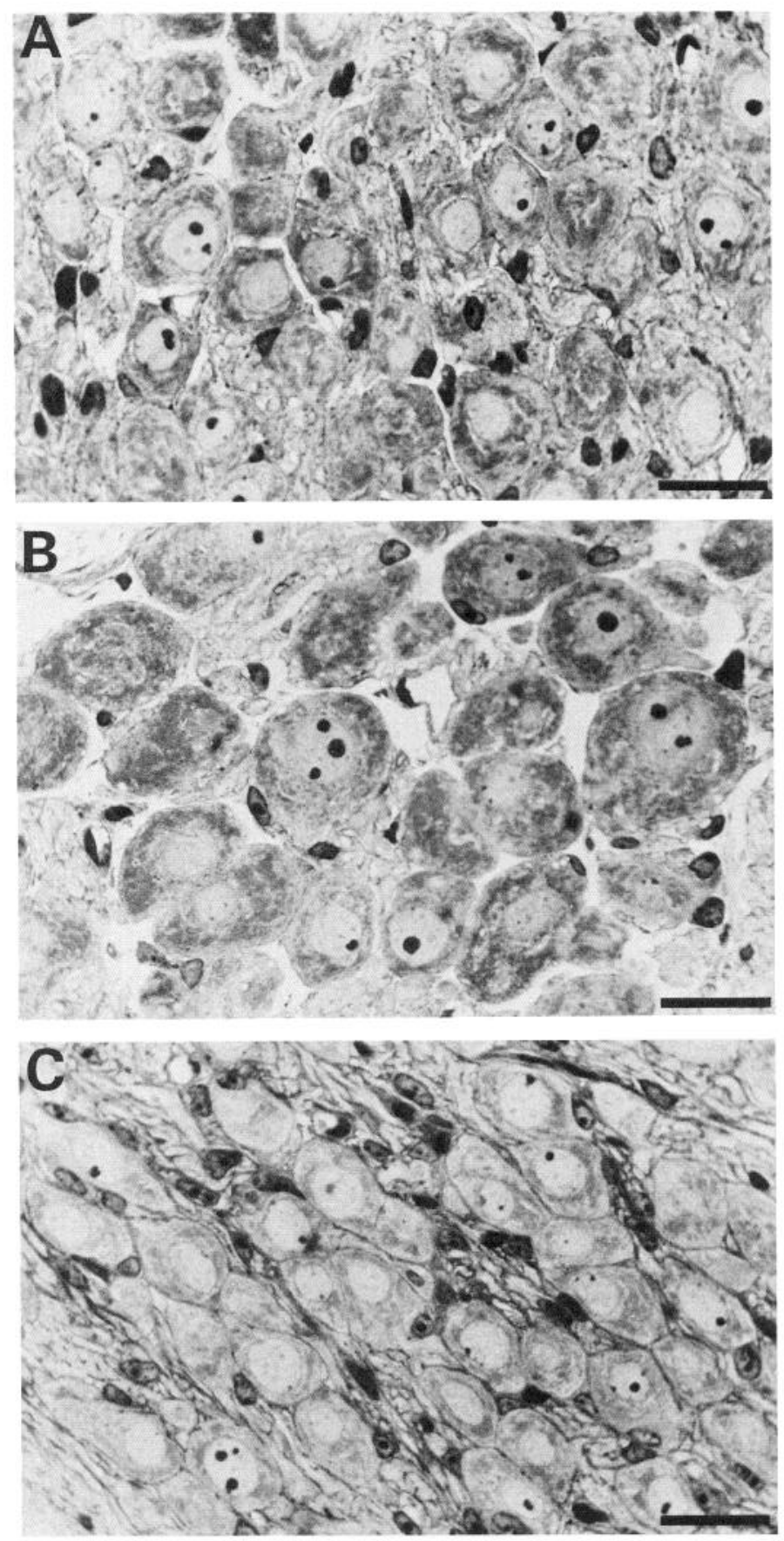

Figure 4. $A-C$, Photomicrographs of neurons within the stellate ganglion of a control animal $(A)$, an NGF-treated animal $(B)$, and an NGF antiserum-treated animal $(C)$ illustrate the significant differences in adult sympathetic ganglion cell body sizes in response to increased levels of NGF or NGF deprivation. Scale bars, $25 \mu \mathrm{m}$.

ment, there was a $25 \%$ decrease in the number of neurons in the ganglion (Table 3). This neuronal loss was progressive over time, and after 3 months of NGF antiserum treatment, $41 \%$ of the neurons had died. In animals treated for 3 months with antiserum of high antibody titer (8000), cell loss was $70 \%$. A caveat in interpreting these results is that, in the presence of severe atrophy, it may be difficult to distinguish neurons from nonneuronal cells. Thus, the degree of cell death may be overestimated. 
Table 2. Effects of NGF or NGF antiserum treatment on sympathetic ganglion cell size

\begin{tabular}{lll} 
Treatment group & $\begin{array}{l}\text { Number of } \\
\text { animals }\end{array}$ & $\begin{array}{l}\text { Cell cross- } \\
\text { sectional area } \\
\left(\mu \mathrm{m}^{2}\right)\end{array}$ \\
\hline 2 weeks control & 4 & $325(17)$ \\
2 weeks NGF & 4 & $473(9)^{a}$ \\
1 month control & 4 & $301(13)$ \\
1 month anti-NGF & 4 & $224(5)^{a}$ \\
3 months control & 3 & $414(19)$ \\
3 months anti-NGF & 4 & $284(22)^{a}$ \\
Aged 1 month control & 3 & $347(12)$ \\
Aged 1 month anti-NGF & 3 & $276(22)^{a}$
\end{tabular}

Mean values are given \pm SEM.

Measurements were made by using at least 50 cell profiles from the stellate ganglia of each animal.

${ }^{a}$ Values significantly different from controls ( $p<0.001$ by Student's $t$-test).

\section{Effects of $N G F$ antiserum in aged animals}

Soma size and ganglion cell survival were assessed in aged animals ( 22 months old) that had been treated for 1 month with NGF antiserum. After the treatment period, stellate ganglion cell cross-sectional areas were decreased $21 \%$ compared to a $26 \%$ reduction in the young adult animals. Cell counts in the right superior cervical ganglion were reduced $22 \%$ after antiserum treatment compared to a $25 \%$ reduction in the young adults. It appears from our data that aged animals (22 months old) are no more or less sensitive to endogenous levels of NGF than are young adult animals. From our data, there appears to be a significant decrease in the number of cells in the superior cervical ganglia of aged control animals $(7388 \pm 460)$ compared to young adult control animals $(10,167 \pm 482)$. The issue of the extent of neuronal loss in sympathetic ganglia during aging is currently under investigation.

\section{Discussion}

In this study we have characterized the responses of sympathetic ganglion cells in sexually mature and aged mice to exogenous administration of NGF or its antiserum. Our results are in agreement with previous studies using autoimmune animals in showing that sympathetic ganglion cells retain a dependence on NGF for survival in maturity (Gorin and Johnson, 1980; Johnson et al., 1982), and we show that this NGF dependence extends into old age. Furthermore, we show that administration of NGF to adult animals causes increases in the total length of sympathetic ganglion cell dendrites, and that treatment with NGF antiserum results in a retraction of dendritic arborizations.

Intracellular staining of ganglion cells allows for a detailed examination of morphological responses to exogenous NGF administration or NGF deprivation by treatment with specific antisera. In our hands, Lucifer yellow-injected cells in fixed ganglia exhibited total dendritic lengths that agree with previously published results from cells injected with HRP in the living ganglia of mice at comparable ages and weights (Yawo, 1987). Although a disadvantage in the use of Lucifer yellow in fixed tissuc appcars to bc its inability to fill small axonal collaterals (Buhl and Lubke, 1989), major changes in cell body size or dendritic architecture in response to treatment can be confidently assessed.

The most significant change in neuronal geometry in response
Table 3. Effects of NGF antiserum treatment on superior cervical ganglion cell survival

\begin{tabular}{|c|c|c|c|c|}
\hline Treatment group & $\begin{array}{l}\text { Raw } \\
\text { count }\end{array}$ & $\begin{array}{l}\text { Cor- } \\
\text { rection } \\
\text { factor }\end{array}$ & $\begin{array}{l}\text { Cor- } \\
\text { rected } \\
\text { count }\end{array}$ & $\begin{array}{l}\text { Corrected } \\
\text { mean } \pm \text { SEM }\end{array}$ \\
\hline \multirow{5}{*}{$\begin{array}{l}1 \text { month control } \\
(n=5 \text { animals })\end{array}$} & 22,680 & 0.51 & 11,567 & \multirow[t]{5}{*}{$10,167 \pm 482$} \\
\hline & 19,385 & 0.48 & 9305 & \\
\hline & 22,388 & 0.49 & 10,970 & \\
\hline & 21,147 & 0.47 & 9939 & \\
\hline & 18,104 & 0.50 & 9052 & \\
\hline \multirow{6}{*}{$\begin{array}{l}1 \text { month anti-NGF } \\
(n=6 \text { animals })\end{array}$} & 12,656 & 0.48 & 6075 & \multirow[t]{6}{*}{$7677 \pm 436$} \\
\hline & 15,976 & 0.48 & 7668 & \\
\hline & 17,060 & 0.54 & 9212 & \\
\hline & 14,972 & 0.49 & 7336 & \\
\hline & 13,116 & 0.56 & 7345 & \\
\hline & 14,283 & 0.59 & 8427 & \\
\hline \multirow{4}{*}{$\begin{array}{l}3 \text { months anti-NGF } \\
(1: 1000 \text { antibody titer; } \\
n=4 \text { animals })\end{array}$} & 10,875 & 0.45 & 4894 & \multirow[t]{4}{*}{$6012 \pm 425$} \\
\hline & 14,112 & 0.44 & 6209 & \\
\hline & 13,629 & 0.44 & 5997 & \\
\hline & 15,436 & 0.45 & 6946 & \\
\hline \multirow{2}{*}{$\begin{array}{l}3 \text { months anti-NGF } \\
(1: 8000 \text { antibody titer; } \\
n=2 \text { animals })\end{array}$} & 5712 & 0.50 & 2856 & \multirow[t]{2}{*}{$3041 \pm 185$} \\
\hline & 6450 & 0.50 & 3225 & \\
\hline \multirow{3}{*}{$\begin{array}{l}\text { Aged control } \\
\qquad(n-3 \text { animals })\end{array}$} & 12,725 & 0.51 & 6490 & \multirow[t]{3}{*}{$7388 \pm 460$} \\
\hline & 15,028 & 0.51 & 7664 & \\
\hline & 14,562 & 0.55 & 8009 & \\
\hline \multirow{3}{*}{$\begin{array}{l}\text { Aged anti-NGF } \\
\qquad(n=3 \text { animals })\end{array}$} & 10,620 & 0.53 & 5629 & \multirow[t]{3}{*}{$5794 \pm 102$} \\
\hline & 11,072 & 0.54 & 5979 & \\
\hline & 10,893 & 0.53 & 5773 & \\
\hline
\end{tabular}

Correction factors were calculated by the Abercrombie (1946) formula (section thickness/average nuclear diameter + section thickness).

to NGF treatment was increased dendritic branching. The new branches were elaborated at secondary, tertiary, and higher levels; these ganglion cells did not exhibit any new primary dendrites. Since preganglionic terminals make synaptic contact primarily on dendritic branches (Forehand, 1985), the ability of NGF to regulate dendritic branching is potentially important for changes in connectivity within the ganglion. In addition, these results are interesting in light of the demonstrated ability of sympathetic ganglion cell dendritic arborizations to elongate and branch in adult animals (Purves and Hadley, 1985; Purves et al., 1986a; Voyvodic, 1987). Dendritic arborizations continue to expand after sexual maturity through the first year of life, and this dendritic growth occurs in parallel with increases in animal body weight (Voyvodic, 1987). Our results suggest that an increase in the amount of NGF elaborated by a growing target may be a means by which this ongoing dendritic growth is stimulated.

Target-derived trophic support of sympathetic ganglion cell morphology in the adult has been previously suggested on the basis of the results of axotomy experiments. Yawo (1987) has demonstrated that sympathetic ganglion cell dendritic arborizations retract after a crush injury of the postganglionic nerve, and these changes are reversible as the axons reinnervate the target. Our observations of dendritic retraction as well as abnormalities, such as dendritic sprouting and club-likc cndings on dendritic branches after treatment with NGF antiserum, are similar to changes that Yawo described after axotomy. Thus, NGF deprivation may be the explanation for the effects of axotomy on adult sympathetic ganglion cell dendritic arboriza- 
tions. In support of this conclusion, Njå and Purves (1978) found that NGF could largely prevent chromatolytic changes and loss of synapses from sympathetic ganglion cells after axotomy.

The ability of neurons and their dendrites to be modulated to grcater or lesser degrees of complexity by administration or deprivation of NGF suggests that similar events could occur during the life of the animal if the endogenous supply of trophic factor were changed. A similar conclusion was reached by Hagg et al. (1989), who showed that forebrain cholinergic neurons in the adult rat hypertrophy in response to NGF. These experiments suggest that adult neurons are normally under the influence of "less than maximal" support by neurotrophic substances from their target, as is clearly the case during development (Angeletti et al., 1971b; Snider, 1988). The recent demonstration that the level of production of NGF by certain cell types can be altered dramatically by humoral factors (Lindholm et al., 1987) may therefore have important consequences for the regulation of neural organization within peripheral sympathetic ganglia of adult animals.

Not all parameters of dendritic morphology were affected by NGF treatment. For example, we did not observe any change in the number of primary dendrites between controls and animals treated with either NGF or its antiserum. This result agrees with the findings of Purves et al. (1986a), who observed increases in dendritic length associated with increased branching within the arbor and not by the addition of new primary dendrites in any repeatedly identified cells in living mice followed for periods up to 3 months. The number of primary dendrites a sympathetic ganglion cell elaborates is a relatively stable morphological feature that is set early in development and changes little after birth while, in contrast, other parameters of dendritic complexity are changing dramatically (Voyvodic, 1987). However, even the number of primary dendrites can be affected by NGF if it is administered during early postnatal development (Snider, 1988). Although mature sympathetic ganglion cells remain dependent on NGF and retain a capacity to respond to increased levels of NGF, age imparts limits on how plastic these neurons actually can be.

The effects of treatment of adult animals with NGF antiserum are in agreement with previous work in autoimmune animals (Gorin and Johnson, 1980; Johnson et al., 1982) where cell survival was significantly affected. The cell loss appears to be gradual and progressive over time. Our data show that NGF antiserum antibody titers of 1000 in twice-per-week treatments resulted in a progressive loss of ganglion cells leading to a $41 \%$ decrease in cell number over 3 months of treatment. The titer of antibody may be significant, as higher serum antibody titers (8000) lead to even more extensive cell death over the 3 month treatment period.

In summary, our results demonstrate that adult sympathetic neurons remain sensitive to NGF and require this factor for maintenance of dendritic morphology as well as survival. Thus, even in adulthood, sympathetic neurons retain morphological plasticity that could be regulated by target levels of NGF. These observations may be relevant to understanding rearrangements in neuronal circuitry that have been demonstrated in autonomic ganglia of adult mice (Purves and Hadley, 1985; Purves et al., 1986a; Purves et al., 1987).

\section{References}

Abercrombie M (1946) Estimation of nuclear population from microtome sections. Anat Rec 94:239-247.
Angeletti PU, Levi-Montalcini R, Caramia F (1971a) Analysis of the effects of the antiserum to the nerve growth factor in adult mice. Brain Res 27:343-355.

Angeletti PU, Levi-Montalcini R, Caramia F (1971b) Ultrastructural changes in sympathetic neurons of newborn and adult mice treated with ncrve growth factor. J Ultrastructure Res 36:24-36.

Bjerre B, Bjorklund A, Mobley W, Rosengren E (1975a) Short- and long-term effects of nerve growth factor on the sympathetic nervous system in the adult mouse. Brain Res 94:263-277.

Bjerre B, Niklund L, Edwards DC (1975b) A study of the de- and regenerative changes in the sympathetic nervous system of the adult mouse after treatment with the antiserum to nerve growth factor. Brain Res 92:257-278.

Bocchini F, Angeletti PU (1969) The nerve growth factor: purification as a 30,000 molecular weight protein. Proc Natl Acad Sci USA 64: 787-794.

Buhl EH, Lubke J (1989) Intracellular lucifer yellow injection in fixed brain slices combined with retrograde tracing, light and electron microscopy. Neuroscience 28:3-16.

Chun LL, Patterson PH (1977) Role of nerve growth factor in the development of rat sympathetic neurons in vitro. J Cell Biol 75:705711.

Fenton EL (1970) Tissue culture assay of nerve growth factor and of the specific antiserum. Exp Cell Res 59:383-392.

Forehand CJ (1985) Density of somatic innervation on mammalian autonomic ganglion cells is inversely related to dendritic complexity and preganglionic convergence. J Neurosci 5:3403-3408.

Goedert M, Otten U, Thoenen H (1978) Biochemical effects of antibodies against nerve growth factor on developing and differentiated sympathetic ganglia. Brain Res 148:264-268.

Gorin PD, Johnson EM (1979) Experimental autoimmune model of nerve growth factor deprivation: effects on developing peripheral sympathetic and sensory neurons. Proc Natl Acad Sci USA 76:53825386.

Gorin PD, Johnson EM (1980) Effects of long-term nerve growth factor deprivation on the nervous system of the adult rat: an experimental autoimmune approach. Brain Res 198:27-42.

Greene LA (1977) Quantitative in vitro studies on the nerve growth factor (NGF) requirement of neurons. I. Sympathetic neurons. Dev Biol 58:96-105.

Hagg T, Hagg F, Vahlsing HL, Manthorpe M, Varon S (1989) Nerve growth factor effects on cholinergic neurons of neostriatum and nucleus accumbens in the adult rat. Neuroscience 30:95-103.

Hefti $F$ (1986) Nerve growth factor promotes survival of septal cholinergic neurons after fimbrial transections. J Neurosei 6:21 55-2162.

Hendry IA, Campbell J (1976) Morphometric analysis of rat superior cervical ganglion after axotomy and nerve growth factor treatment. J Neurocytol 5:351-360.

Higgins GA, Koh S, Chen KS, Gage FH (1989) NGF induction of NGF receptor gene expression and cholinergic neuronal hypertrophy within the basal forebrain of the adult rat. Neuron 3:247-256.

Johnson EM, Gorin PD, Osborne PA, Rydel RE, Pearson J (1982) Effects of autoimmune NGF deprivation in the adult rabbit and offspring. Brain Res 240:131-140.

Johnson MI (1983) Dissociated neurons from adult rat superior cervical ganglion show reduced NGF requirements in culture. Soc Neurosci Abstr 9:846.

Kromer L (1987) Nerve growth factor treatment after brain injury prevents neuronal death. Science 235:214-216.

Levi-Montalcini R, Booker B (1960) Destruction of the sympathetic ganglia in mammals by an anti-serum to the nerve growth factor. Proc Natl Acad Sci USA 46:384-391.

Levi-Montalcini R, Angeletti PU (1966) Immunosympathectomy. Pharmacol Rev 18:619-628.

Lindholm D, Heumann R, Meyer M, Thoenen H (1987) Interleukin-1 regulates synthesis of nerve growth factor in non-neuronal cells of rat sciatic nerve. Nature 330:658-659.

Lindsay RM (1988) Nerve growth factors (NGF, BDNF) enhance axonal regeneration but are not required for survival of adult sensory neurons. J Neurosci 8:2394-2405.

Martin DP, Schmidt RE, DiStefano PS, Lowry OH, Carter JG, Johnson EM (1988) Inhibitors of protein synthesis and RNA synthesis prevent neuronal death caused by nerve growth factor deprivation. J Cell Biol 106:829-844.

$\mathrm{Njå} \mathrm{A,} \mathrm{Purves} \mathrm{D} \mathrm{(1978)} \mathrm{The} \mathrm{effects} \mathrm{of} \mathrm{nerve} \mathrm{growth} \mathrm{factor} \mathrm{and} \mathrm{its}$ 
antiserum on synapses in the superior cervical ganglion of the guineapig. J Physiol (Lond) 277:53-75.

Otten U, Goedert M, Schwab M, Thibault J (1979) Immunization of adult rats against $2.5 \mathrm{~S}$ NGF: effects on the peripheral sympathetic nervous system. Brain Res 176:79-90.

Purves D, Hadlcy RD (1985) Changes in the dendritic branching of adult mammalian neurones revealed by repeated imaging in situ. Nature 315:404-406.

Purves D, Hadley RD, Voyvodic JT (1986a) Dynamic changes in the dendritic geometry of individual neurons visualized over period of up to three months in the superior cervical ganglion of living mice. J Neurosci 6:1051-1060.

Purves D, Rubin E, Snider WD, Lichtman J (1986b) Relation of animal size to convergence, divergence, and neuronal number in peripheral sympathetic pathways. J Neurosci 6:158-163.

Purves D, Voyvodic JT, Magrassi L, Yawo H (1987) Nerve terminal remodeling visualized in living mice by repeated examination of the same neuron. Science 238:1122-1126.

Ramoa AS, Campbell G, Shatz CJ (1988) Dendritic growth and remodeling of cat retinal ganglion cells during fetal and postnatal dcvelopment. J Neurosci 8:4239-4261.

Rich KM, Yip HK, Osborne PA, Schmidt RE, Johnson EM (1984) Role of nerve growth factor in the adult dorsal root ganglion neuron and its response to injury. J Comp Neurol 230:110-118.

Richardson PM, Verge Issa VMK, Riopelle RJ (1986) Distribution of neuronal receptors for nerve growth factor in the rat. J Neurosci $6: 2312-2321$
Scholl DA (1953) Dendritic organization in the neurons of the visual and motor cortices of the cat. J Anat 87:387-406.

Snider WD (1988) Nerve growth factor enhances dendritic arborization of sympathetic ganglion cells in developing mammals. J Neurosci 8:2628-2634.

Taniuchi M, Schwcitzer JB, Johnson EM (1986) Nerve growth factor receptor molecules in rat brain. Proc Natl Acad Sci USA 83:19501954.

Thoenen H, Angeletti PU, Levi-Montalcini R, Kettler R (1971) Selective induction of tyrosine hydroxylase and dopamine $\beta$-hydroxylase in rat superior cervical ganglia by nerve growth factor. Proc Natl Acad Sci USA 68:1598-1602.

Voyvodic JT (1986) A general purpose image processing language (IMAGR) facilitates visualizing neuronal structures in fixed tissue and in vivo. Soc Neurosci Abstr 12:390.

Voyvodic JT (1987) Development and regulation of dendrites in the rat superior cervical ganglion. J Neurosci 7:904-912.

Voyvodic JT (1989) Peripheral target regulation of dendritic geometry in the rat superior cervical ganglion. J Neurosci 9:1997-2010.

Williams LR, Varon S, Peterson GM, Wictorin K, Fischer W, Bjorklund A, Gage FH (1986) Continuous infusion of nerve growth factor prevents basal forebrain neuronal death after fimbria fornix transection. Proc Natl Acad Sci USA 83:9231-9235.

Yawo $\mathrm{H}$ (1987) Changes in the dendritic geometry of mouse superior cervical ganglion cells following postganglionic axotomy. J Neurosci 7:3703-3711. 